Tropical Journal of Pharmaceutical Research January 2017; 16 (1): 165-169

ISSN: $1596-5996$ (print); 1596-9827 (electronic)

(c) Pharmacotherapy Group, Faculty of Pharmacy, University of Benin, Benin City, 300001 Nigeria.

All rights reserved.

Available online at http://www.tjpr.org

Original Research Article

http://dx.doi.org/10.4314/tjpr.v16i1.22

\title{
Extraction and characterization of radish seed oils using different methods
}

\author{
Gongling Zhao ${ }^{1 *}$, Yupeng Ren $^{2}$ and Hanjun $\mathrm{Ma}^{1}$ \\ ${ }^{1}$ School of Food Science, Henan Institute of Science and Technology, Xinxiang 453003, ${ }^{2}$ Henan Vocational College of \\ Chemical Technology, Zhengzhou 450042, China
}

*For correspondence: Email: hnzgl@163.com

Received: 24 September 2016

Revised accepted: 18 December 2016

\begin{abstract}
Purpose: To evaluate the impact of three different extraction methods on oil yield, physicochemical properties and bioactive ingredients of radish seeds.

Methods: Radish seed oil was prepared by traditional solvent extraction (SE), supercritical carbon dioxide extraction (SCE) and sub-critical propane extraction (SPE). The yield, physicochemical properties, fatty acid composition and oxidative stability of the oil extracts were compared. The contents of tocopherol and sulforaphene in the oils were also determined.

Results: The oil yield obtained by SPE, SE, SCE were 33.69, 27.17 and $24.10 \%$, respectively. There were no significant differences in physicochemical properties and fatty acid composition of oils extracted by the three methods. However, SCE oil had the best oxidative stability, and highest contents of vitamin $E$ and sulforaphene, followed by oils from SPE and SE

Conclusion: SCE is highly selective for tocopherol and sulforaphene, which could explain its high oil oxidative stability. These results suggest that of the three extraction methods, SCE is best suited for preparing medicinal radish seed oil.
\end{abstract}

Keywords: Radish seed oil, Different extraction methods, Fatty acid composition, Tocopherol, Sulforaphene

Tropical Journal of Pharmaceutical Research is indexed by Science Citation Index (SciSearch), Scopus, International Pharmaceutical Abstract, Chemical Abstracts, Embase, Index Copernicus, EBSCO, African Index Medicus, JournalSeek, Journal Citation Reports/Science Edition, Directory of Open Access Journals (DOAJ), African Journal Online, Bioline International, Open-J-Gate and Pharmacy Abstracts

\section{INTRODUCTION}

There is sufficient scientific evidence indicating that consumption of radish (Raphanus sativus L.) has positive influence on reduction of risks of a number of cancers and cardiovascular diseases, due to its content of some beneficial phytochemicals [1-3]. In traditional Chinese medicine, radish seed oil, which is rich in sulforaphene is used to improve intestinal function and for treatment of digestive problems [4]. Studies have shown that oil yields from radish seeds can be as high as 35-40\%, making them potential new oil sources for food, medicine and cosmetic industries [5].
The quality and safety of natural extracts used as functional foods and medicines must conform with strict regulations related to residual levels of solvents. This necessitates the development and application of new extraction methods in food and pharmaceutical industries [6]. Super-critical carbon dioxide extraction (SCE) and sub-critical propane extraction (SPE) have been widely accepted and used in the extraction of oils and phytochemicals $[7,8]$. However, there are no reports so far on the use of these techniques for preparation of radish seed oil. In this study, SE, SCE and SPE were used to extract oil from radish seeds. Oil yields, as well as 
physicochemical properties and bioactive ingredients of the oils were compared.

\section{EXPERIMENTAL}

\section{Materials and chemicals}

Radish seeds were purchased from Wuhan Vegetable Research Institute (Wuhan, China). Standard fatty acid methyl esters, tocopherols ( $\alpha$, $\beta-, \quad \gamma^{-}$, and $\delta$-isomers) and sulforaphene were procured from Sigma Chemical Co. (St Louis, MO). All other reagents were of analytical grade.

\section{Determination of proximate composition}

The content of moisture, ash, crude lipid, crude protein and crude fiber in the radish seeds were determined by the AOCS Official Methods [9] and expressed on a wet weight basis.

\section{Solvent extraction (SE)}

Radish seed powder was prepared by grinding portions of the seeds in a clean coffee grinder for $15 \mathrm{~s}$. The radish seed powder $(1000 \mathrm{~g})$ was subsequently soaked in $5000 \mathrm{~mL}$ of $\mathrm{n}$-hexane for $5 \mathrm{~h}$ at $25^{\circ} \mathrm{C}$ and filtered. The residue obtained was again extracted with $5000 \mathrm{~mL}$ of $\mathrm{n}$-hexane. The supernatants from both steps were collected, combined and concentrated by using Rotary evaporator under vacuum at $40{ }^{\circ} \mathrm{C}$ to remove $\mathrm{n}$-hexane. The oil obtained was weighed and stored at $4{ }^{\circ} \mathrm{C}$ prior to analysis.

\section{Supercritical carbon dioxide extraction (SCE)}

SCE extraction was performed on a 10 L-SFE system (Masson Nem, Guangzhou, China), consisting of an extraction vessel (10 L) and two separators. Radish seed bran powder $(1200 \mathrm{~g})$ was put into the extractor and extracted at 26 $\mathrm{mPa}$ at $45^{\circ} \mathrm{C}$ for $2.5 \mathrm{~h}$. The operating conditions for the two separators were set at $7.5 \mathrm{mPa}$ at 50 ${ }^{\circ} \mathrm{C}$ and $5 \mathrm{mPa}$ at $30{ }^{\circ} \mathrm{C}$, respectively. The flow rate of liquid $\mathrm{CO}_{2}$ was $35 \mathrm{~L} / \mathrm{h}$. The oil in the separators was collected, weighed and stored at $4{ }^{\circ} \mathrm{C}$ for analysis.

\section{Sub-critical propane extraction (SPE)}

SPE extraction was performed on a CBE-5L subcritical fluid extraction system (Henan Yalinjie Biological Technology CO., LTD, Anyang, China). The radish seed bran powder (1200 g) was loaded into the extractor and extracted at a pressure of $0.4 \mathrm{mPa}$ and temperature of $40{ }^{\circ} \mathrm{C}$ for $2.5 \mathrm{~h}$. Evaporating temperature was set at 40 ${ }^{\circ} \mathrm{C}$. The resultant oil in the separators was collected, weighed and stored at $4{ }^{\circ} \mathrm{C}$ prior to analysis.

\section{Determination of physicochemical properties}

The density, refractive index, saponification value and peroxide value of each of the oils were measured by the IUPAC Methods [10] Oil color was determined according to the AOCS Official Method [11].

\section{Determination of fatty acid composition}

Fatty acid compositions of the oil samples were analyzed according to the IUPAC method 2.302 [12], with an Agilent 6890N gas chromatograph (Agilent Technologies Co., Ltd.), fitted with a flame ionization detector. The column used was a DB-FFAP capillary column; the film thickness was $0.25 \mu \mathrm{m}$. The length of the column was $30 \mathrm{~m}$ and its internal diameter was $0.32 \mathrm{~mm}$. The column, injector, and detector temperatures were set at 180,230 , and $230^{\circ} \mathrm{C}$, respectively. The flow rate of the $\mathrm{N}_{2}$ carrier gas with a split ratio of $1: 20$ was set at $70 \mathrm{~mL} / \mathrm{min}$.

\section{Determination of tocopherol composition}

Tocopherol ( $\alpha$-, $\beta$ - and $\gamma$ - isomers) contents of the oils were estimated according to the method of Shi et al [13], using an LC-10Avp High Performance Liquid Chromatography (Shimadzu, Japan), fitted with a RF-10AXL fluorescence detector (Shimadzu, Kyoto, Japan). Each oil was dissolved in $\mathrm{n}$-hexane and eluted on a silica column $(250 \times 4.6 \mathrm{~mm}, 5 \mu \mathrm{m})$ (Dalian Yilite, Dalian, China) with $\mathrm{n}$-hexane:isopropyl ether (99 $: 1, \mathrm{v} / \mathrm{v}$ ratio) at $0.8 \mathrm{~mL} / \mathrm{min}$. Column temperature was set at $40^{\circ} \mathrm{C}$.

\section{Determination of sulforaphene content}

To quantify sulforaphene, a gas chromategraphy-mass spectrometry (GC-MS) was used [14-15]. An Agilent 7890 coupled with an Agilent 5975C mass selective detector and a fused silica capillary column (HP-5, $30 \mathrm{~m} \times 0.25 \mathrm{~mm}, 0.25$ $\mu \mathrm{m}$ of film thickness) were employed. Oven temperature was set at $80{ }^{\circ} \mathrm{C}$ for $1 \mathrm{~min}$, then increased to $150^{\circ} \mathrm{C}$ at the rate of $20^{\circ} \mathrm{C} / \mathrm{min}$ and then to $280{ }^{\circ} \mathrm{C}$ at the rate of $40^{\circ} \mathrm{C} / \mathrm{min}$ and held at $280^{\circ} \mathrm{C}$ for $3 \mathrm{~min}$. Injector temperature was at $250^{\circ} \mathrm{C}$; carrier gas (helium) was at a flow rate of $1 \mathrm{~mL} / \mathrm{min}$; ionization energy was $70 \mathrm{eV}$; mass range was $40-500 \mathrm{~m} / \mathrm{z}$ and scan mode was on electron impact. One microliter of the sample was injected with a split ratio of $1: 20$, and the data were recorded and processed by Xcalibur software. 


\section{Determination of oil oxidative stability}

The oxidative stabilities of the oils were determined on a 743 Rancimat analyzer (Metrohm, Switzerland) [16]. Each oil sample (5 g) was subjected to oxidation at $110{ }^{\circ} \mathrm{C}$ with air flow rate of $20 \mathrm{~L} / \mathrm{h}$. The induction period was recorded automatically.

\section{RESULTS}

\section{Proximate composition}

The proximate composition of radish seed is shown in Table 1 below. The crude lipid content was $35.46 \%$, which is higher than that of soya bean.

Table 1: Proximate composition (\%) of radish seed

\begin{tabular}{lcccc}
\hline Moisture & Ash & $\begin{array}{c}\text { Crude } \\
\text { lipid }\end{array}$ & $\begin{array}{c}\text { Crude } \\
\text { protein }\end{array}$ & $\begin{array}{c}\text { Crude } \\
\text { fiber }\end{array}$ \\
\hline 6.57 & 4.71 & 35.46 & 18.48 & 10.05 \\
\hline
\end{tabular}

\section{Oil yield}

The different extracting methods yielded different levels of oil. Traditional SE method with nhexane for $5 \mathrm{~h}$ at $25^{\circ} \mathrm{C}$ gave an oil yield of 27.17 $\%(\mathrm{w} / \mathrm{w})$. The yield from SCE method at $26 \mathrm{mPa}$ in $45{ }^{\circ} \mathrm{C}$ for $2.5 \mathrm{~h}$ was $24.10 \%(\mathrm{w} / \mathrm{w})$ while SPE method at $0.4 \mathrm{mPa}$ in $40^{\circ} \mathrm{C}$ for $2.5 \mathrm{~h}$ was 33.69 $\%(w / w)$.

\section{Tocopherol composition}

Results of tocopherol composition of the oils obtained by SE, SCE and SPE showed that $\gamma$ tocopherol was the major fatty acid component. The content of $y$-tocopherol in SCE oil was as high as $538.90 \mathrm{mg} / 100 \mathrm{~g}$, while the contents of $\mathrm{Y}^{-}$ tocopherol oils from SE and SPE were only 95.76 and $202.86 \mathrm{mg} / 100 \mathrm{~g}$, respectively. Oil from SE had the highest contents of $\alpha$-tocopherol and $\beta$-tocopherol, (27.08 and $9.32 \mathrm{mg} / 100 \mathrm{~g}$ respectively), followed by SPE oil (19.32 and $8.38 \mathrm{mg} / 100 \mathrm{~g}$, respectively). The least was SCE, with 8.85 and $4.26 \mathrm{mg} / 100 \mathrm{~g}$, respectively.
The variation pattern of $\delta$-tocopherol and total tocopherol in the oils was similar to that of $\mathrm{y}^{-}$ tocopherol.

\section{Sulforaphene contents}

Sulforaphene content of the oil obtained by SCE was the highest $(53.34 \mathrm{mg} / \mathrm{kg})$, followed by SPE and SE, which yielded 27.65 and $13.72 \mathrm{mg} / \mathrm{kg}$, respectively.

\section{Oil oxidative stability}

The induction periods of the oils obtained by SE, SCE and SPE were 4.99, 38.51 and $10.08 \mathrm{~h}$. The oxidative stability of oil from SCE was significantly higher than that from SE or SPE. This may be attributed to the high contents of tocopherol and sulforaphene in the SCE oil.

\section{DISCUSSION}

Traditional extraction methods which use large amounts of toxic solvents to extract plant oils have many drawbacks, such as time factor, residual solvents in oils, and low output rate. Modern extraction methods can solve these problems. Supercritical carbon dioxide extraction (SCE) and subcritical propane extraction (SPE) are the most promising technologies for overcoming the disadvantages of traditional extraction protocols [17]. In this study, three extraction methods (SE, SCE and SPE) were used to extract radish seed oil. The physicochemical properties and bioactive ingredients of the resultant oils were compared. SPE was superior to SCE with respect to extraction yield of oil from radish seeds. This is related to the fact that subcritical propane is a better solvent for triacylglycerols than supercritical carbon dioxide $[18,19]$.

The effect of the extraction methods on traditional physicochemical properties (density, refractive index, saponification value, peroxide value and iodine value) was not significant. However, the peroxide values of SE, SCE and SPE were lower than those generally recommended for commercial vegetable oils [20].

Table 2: Physicochemical properties of radish seed oils obtained by different extraction methods

\begin{tabular}{lccc}
\hline Parameter & SE & SCE & SPE \\
\hline Density & 0.90 & 0.92 & 0.91 \\
Refractive index & 1.47 & 1.47 & 1.47 \\
Saponification value & 182.10 & 183.90 & 184.70 \\
Peroxide value (meq/kg) & 1.78 & 0.69 & 1.68 \\
lodine value & 94.64 & 101.53 & 99.17 \\
Color (Lovibond, 1 in.) & Y25.00, R2.00 & Y30.00, R1.50 & Y35.00, R2.60 \\
\hline
\end{tabular}


The color of the oil obtained by SPE was deeper than that of SE or SCE, which implies that it had higher contents of natural pigments (such as carotenoids). The oils obtained by the different extraction methods showed similar fatty acid compositions, with high erucic acid content, which could partly explain the medicinal importance of radish seed oil in Chinese traditional medicine. Although the oil yield of SPE was the highest, its bioactive ingredients (tocopherol and sulforaphene) were lower than those of SCE, which suggests that its extraction potential was lower than that of SCE. The high contents of tocopherol and sulforaphene probably conferred high oxidative stability on the oil obtained by SCE.

\section{CONCLUSION}

The effects of the three extraction methods on traditional physicochemical properties and fatty acid composition of the resultant oils were not significant. Due to its high oxidative stability and selectivity for tocopherol and sulforaphene, SCE appears to be the most suitable method for preparing medicinal radish seed oil.

\section{DECLARATIONS}

\section{Acknowledgement}

The financial support provided by the Program for Innovative Research Team (in Science and Technology) in University of Henan Province (13IRTSTHN006) is greatly appreciated.

\section{Conflict of Interest}

No conflict of interest associated with this work.

\section{Contribution of Authors}

The authors declare that this work was done by the authors named in this article and all liabilities pertaining to claims relating to the content of this article will be borne by them.

\section{Open Access}

This is an Open Access article that uses a funding model which does not charge readers or their institutions for access and distributed under the terms of the Creative Commons Attribution License (http://creativecommons.org/licenses/by 14.0) and the Budapest Open Access Initiative (http://www.budapestopenaccessinitiative.org/rea d), which permit unrestricted use, distribution, and reproduction in any medium, provided the original work is properly credited.

\section{REFERENCES}

1. Kuang $P$, Song $D$, Yuan $Q, L v X$, Zhao $D$, Liang $H$. Preparative separation and purification of sulforaphene from radish seeds by high-speed countercurrent chromatography. Food Chem 2013; 136: 309-315.

2. Kuang $P$, Song $D$, Yuan $Q$, Yi $R, L v X$, Liang $H$. Separation and purification of sulforaphene from radish seeds using macroporous resin and preparative highperformance liquid chromatography. Food Chem 2013; 136: 342-347.

3. Zhang J, Zhou X, Fu M. Integrated utilization of red radish seeds for the efficient production of seed oil and sulforaphene. Food Chem 2016; 192: 541-547.

4. Ahangari B, Sargolzaei J. Extraction of pomegranate seed oil using subcritical propane and supercritical carbon dioxide. Theor Found Chem Eng 2012; 46: 258265.

5. Wada M, Kido $H$, Ohyama $K$, Ichibangase $T$, Kishikawa $N$, Ohba Y, Nakashima MN, Kuroda N, Nakashima K. Chemiluminescent screening of quenching effects of natural colorants against reactive oxygen species: Evaluation of grape seed, monascus, gardenia and red radish extracts as multi-functional food additives. Food Chem 2007; 101: 980-986.

6. Herrero M, Cifuentes A, Ibañez E. Sub- and supercritical fluid extraction of functional ingredients from different natural sources: Plants, food-by-products, algae and microalgae: A review. Food Chem 2006; 98: 136-148.

7. Dos Santos Freitas L, de Oliveira JV, Dariva C, Jacques $R A$, Caramão EB. Extraction of grape seed oil using compressed carbon dioxide and propane: Extraction yields and characterization of free glycerol compounds. J Agric Food Chem 2008; 56: 2558-2564.

8. Firestone $D$. Official method and recommended practices of the AOCS, 5th edn. AOCS Press, Champaign 1998.

9. Paquot $C$, Hauntfenne A. IUPAC standard methods for the analysis of oils, fats and derivatives. London: Blackwell; 1987.

10. Liang S, Yang G, Ma Y. Chemical characteristics and fatty acid profile of foxtail millet bran oil. J Am Oil Chem Soc 2010; 87: 63-67.

11. Lim S, Lee J, Kim JK. Analysis of isothiocyanates in newly generated vegetables, Baemuchae (Brassicoraphanus) as affected by growth. Int $J$ Food Sci Tech 2009; 44: 1401-1407.

12. Vaughn SF, Berhow MA. Glucosinolate hydrolysis products from various plant sources: $\mathrm{pH}$ effects, isolation, and purification. Ind Crop Prod 2005; 21: 193202.

13. Shi $Y$, Ma $Y$, Zhang R, Ma H, Liu B. Preparation and characterization of foxtail millet bran oil using sub-critical propane and supercritical carbon dioxide extraction. J Food Sci and Tech 2015; 52: 3099-3104.

14. Oomah, BD, Ladet S, Godfrey, DV, Liang J, Girard B. Characteristics of raspberry (Rubus idaeus L.) seed oil. Food Chem 2000; 69: 187-193. 
15. Stinco CM, Heredia FJ, Vicario IM, Meléndez-Martínez AJ. Interactions between lipophilic antioxidants measured by photochemiluminescence assay and $\alpha$ tocopherol equivalent antioxidant capacity assay as well as the influence of matrix compounds on the lipophilic antioxidant capacity. LWT-Food Sci Technol 2016; 65: 718-724.

16. Reyes N, Reyes I, Tiwari R, Geliebter J. Effect of linoleic acid on proliferation and gene expression in the breast cancer cell line T47D. Cancer Lett 2004; 209: 25-35.

17. Harris WS. Linoleic acid and coronary heart disease. Prostag Leukotr Ess 2008; 79: 169-171.
18. Lanza M, Ndiaye PM, Tavares FW, Oliveira D, Dariva $C$, Oliveira JV. Phase Behavior of Castor Oil in Compressed Propane and n-Butane, J Supercrit Fluids2005; 34: 215-221.

19. Hamdan S, Daood HG, Toth_Markus V. Extraction of cardamom oil by supercritical carbon dioxide and subcritical propane. J Supercrit Fluids2008; 44: 25-30.

20. Tian G, Li Y, Cheng L, Yuan Q, Tang P, Kuang P, Hu J. The mechanism of sulforaphene degradation to different water contents. Food Chem 2016; 194: 1022-1027. 